\title{
MODELING AND SIMULATION OF MICROINVERTER WITH FLYBACK CONVERTER FOR GRID CONNECTED PV SYSTEMS
}

\author{
SOHAM G. DESHPANDE ${ }^{1} \&$ N. R. BHASME ${ }^{2}$ \\ ${ }^{1}$ PG Student, Department of Electrical Engineering, Government College of Engineering, Aurangabad, India \\ ${ }^{2}$ Associate professor, Department of Electrical Engineering, Government College of Engineering, Aurangabad, India

ABSTRACT
Photovoltaic (PV) energy gains popularity, due to increasing demand of renewable energy sources. This paper
presents a module integrated grid tied microinverter for PV system. The microinverter delivers solar energy from a PV
panel to the utility grid. It extracts maximum power from each PV module and harvest more power to the grid. In this
paper, the microinverter, based on interleaved flyback converter and active clamped technique to reduce voltage spike,
are presented. Simulation of PV panel, active clamped interleaved flyback converter and full bridge inverter are
performed using MATLAB/SIMULINK and the results are discussed. Comparison between microinverter and string
inverter is presented with respect to power harvesting at partial shading.
KEYWORDS: Photovoltaic (PV) \& MATLAB/SIMULINK

Received: Jul 02, 2017; Accepted: Jul 22, 2017; Published: Aug 01, 2017; Paper Id.: IJEEERAUG20178

\section{INTRODUCTION}

Nowadays, an interest in the renewable energy increases due to the increased demand of energy concerns about environmental problems like global warming, climate change etc. Conventional energy resources have limited storage on the earth and renewable sources offer clean and abundant amount of alternative energy to conventional sources. Renewable resources, such as solar energy system gained more importance in the last few years as promising and convenient renewable energy resources. [1]

In India, generation of electricity from PV is increasing rapidly in last few years to reach the energy demand and have clean \& green energy. Figure 1 represents the growth of installed capacity of solar energy in India, from 2010 to 2017. Every year, capacity is growing twice that of previous year. Present installed capacity is $12,289 \mathrm{MW}$, and the government is aiming to expand present capacity up to $100 \mathrm{GW}$, according to Ministry of New \& Renewable energy, Government of India [2]. To achieve this goal, various research and development in the field of solar energy are required.

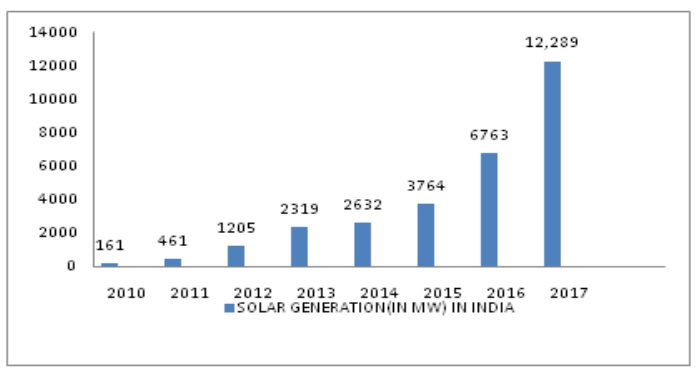

Figure 1: Bar Diagram of Solar Energy Generation Capacity in India 
Inverter is main component in PV power system which is used to convert DC power from PV panel to AC, which is given to load or utility grid. There are various inverter configurations for grid connected PV systems like central inverter, string inverter, multistring inverter and micro inverter. In central inverter system, series-parallel connection of PV panels are connected to high power rating inverter, this inverter configuration has some disadvantages such as partial shading effect, miss-match losses, use of bulky capacitor, common MPPT etc[3]. To overcome this, string inverter system is developed, in which, a number of panels connected in series to form string, and each string has its own inverter, but in this configuration, there are some drawbacks like partial shading occurring on one panel affect overall performance of that string [4]. To mitigate this problem, the micro inverter system is developed, which has small power rating inverter connected to each panel. Inverter structure, operation, converter topology used and merits of micro inverter are discussed in section II. There are various converter topologies that are used to design these grid connected inverters, and these inverters must fulfil the standards of grid connected PV system like THD < 5\%, DC current injection (1\%), galvanic isolation, anti islanding detection etc [5].

\section{MICROINVERTER FOR PV SYSTEM}

Micro inverter topology is the development in the inverter configuration to overcome the losses and drawbacks of the centralized and string inverter system. As shown in Figure 2, the micro inverter topology consist of the module integrated inverter, means each module has its own low rated, small size inverter with separate MPPT for each module, so maximum power is supplied to the grid directly through this micro inverter. Grid connected micro inverter system consist of single PV panel, DC-DC converter for boosting the PV voltage with MPPT, Full bridge inverter (unfolding bridge), EMI filter and grid connection. Main advantage of micro inverter system is to reduce or eliminate the shading and clouding effect in the PV systems. In this topology, if partial shading occurs on one module, it will affects the performance of only that module and performance of the other modules will not be get affected.[1,3]

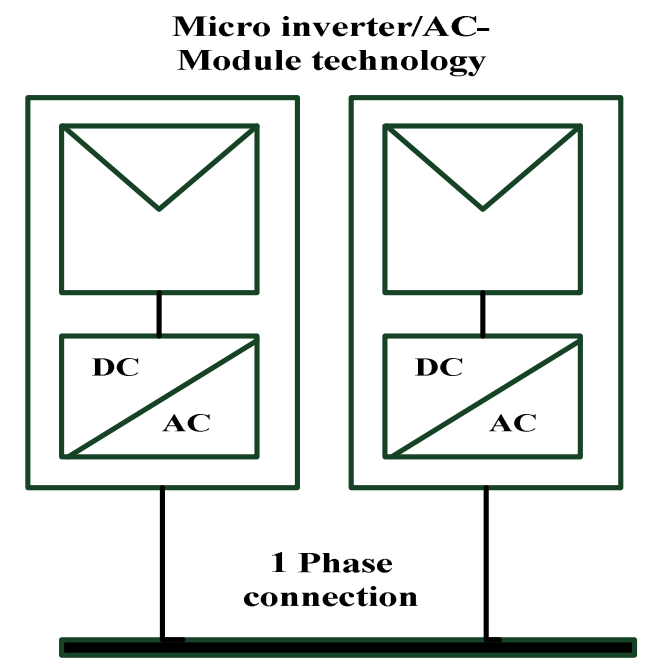

Figure 2: Micro Inverter System

It also gives more accuracy in MPP operation, because each module has its separate MPPT, removing mismatch losses between PV modules. Hence, the energy harvesting to grid increases as compared to the central and string inverter system because of increasing efficiency of the system. Micro inverter topology eliminates the use of DC cables and requirement of the electrolytic capacitor, due to which, the maintenance becomes less and lifespan of the inverter increases (approx. up to 25 years). Design of the micro inverter is flexible and compact. It is like 'Plug-n-Play' device, which can be 
installed and operate easily even by a person, without any knowledge or expertise in the electrical or PV installation. So, the micro inverter configuration gained popularity due to above advantages.[4]

There are various converter topologies used for the design of micro inverter like simple fly back converter, pushpull converter, forward converter and interleaved fly back converter. Mostly, fly back converter is preferred for single phase grid connected micro inverter, because, it is efficient for small power rating, and in micro inverter, only single module is connected, so power rating is low, also it has less components, single stage conversion and galvanic isolation between PV module and grid line.

Forward converter is also step up DC voltage of PV panel and provides galvanic isolation, but when comparing these two converters, the fly back converter requires fewer components than that of the forward converter, as there is no need of output inductor and freewheeling diode at output side, so, fly back topology is selected. Fly back converter is generally used for small low power rating application, so, for increasing a power rating to improve performance of fly back converter, the interleaved structure is used, in which two fly back converters are interleaved to each other. Also, by using interleaved technique, the conduction loss of each switch is reduced and reliability is increases. [6]

\section{SYSTEM DESCRIPTION}

Figure 3 shows the circuit configuration of micro inverter, based on active clamped interleaved fly back converter, also known as interleaved fly back inverter (ILFI). The ILFI consists of decoupling capacitor, first phase fly back converter and second phase fly back converter, which are interleaved to each other, unfolding bridge (full bridge inverter) and EMI filter. ILFI extract DC power from PV panel and harvest AC power to the grid.

Each phase of fly back converter consist of main switches, transformer, diode and active clamp circuit as shown in Figure 3. A clamp circuit is used to decrease the voltage spike across switch. Fly back transformer is used to boost voltage from PV panel and maintain isolation between the PV module and grid line. Unfolding bridge is used to convert rectified AC from interleaved fly back converter to sinusoidal AC, which is compatible to grid. EMI filters are used to remove unwanted harmonics and supply pure AC voltage to grid.[7]

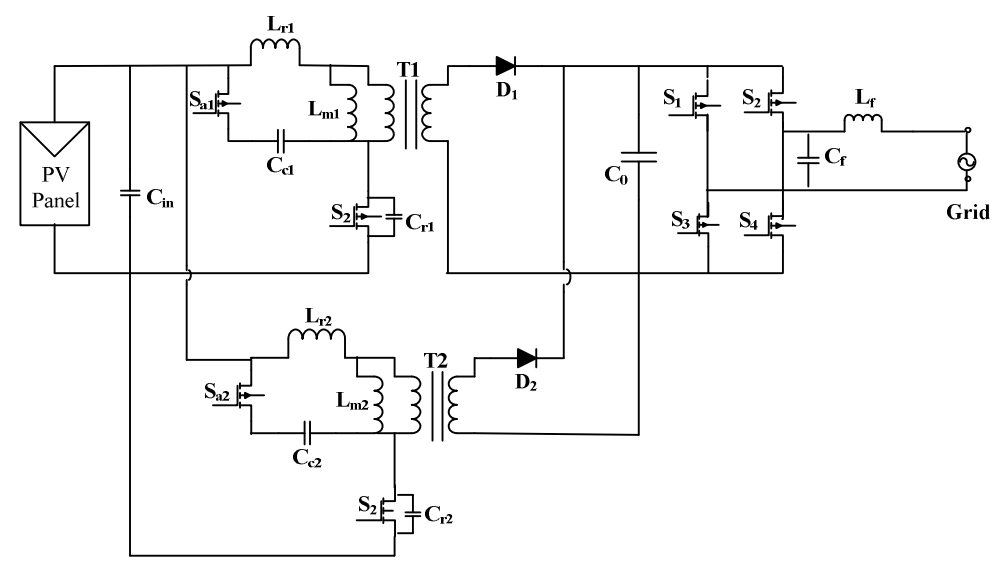

Figure 3: Circuit Configuration of ILFI Based Micro inverter

The operation of active clamped interleaved fly back converter is depending upon the switching of main switches and auxiliary switches. Gate signals given to the main switches $S_{p 1}$ and $S_{p 2}$ are $180^{\circ}$ out of phase, and gate signals to auxiliary active clamped switches $S_{a 1}$ and $S_{a 2}$ are applied to short time, after corresponding main switches are off for 
reducing voltage spike and conduction losses.

\section{DESIGN CONSIDERATIONS}

\subsection{PV Module}

PV module is made up of number of solar cells. The solar cell is P-N junction semiconductor diode. When it is exposed to sunlight, it generates electric current. This generated current is in DC form and varies with change in solar irradiance. Figure 4 represents the equivalent circuit of solar cell. Each cell generates voltage around 0.5 V. So that, for getting high voltage, cells are connected in series and for getting high current, cells are connected in parallel. [8]

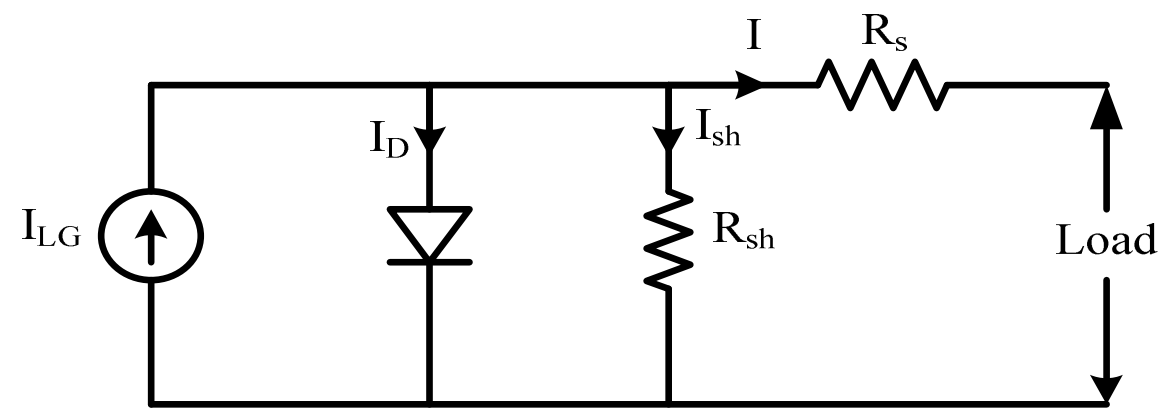

Figure 4: Equivalent Circuit of PV Panel

$$
\begin{aligned}
& I_{d}=I_{o}\left(e^{\frac{q V_{d}}{K T}}-1\right) \\
& V_{d}=V+I R_{s}
\end{aligned}
$$

Final output current equation is given by

$$
I=I_{s c}-I_{o}\left\{\left(e^{\frac{q\left(V+I R_{s}\right)}{K T}}-1\right)\right\}-\left\{\frac{\left(V+I R_{s}\right)}{R_{p}}\right\}
$$

By using equation (3), we can find output current from the PV module.

Where,

$I_{d}$ - Diode current, $\mathrm{I}_{\mathrm{sc}^{-}}$Short circuit current,

$I$ - Output current of solar cell, $V$ - Output voltage of solar cell

$T$ - Cell temperature in Kelvin, $q$ - Electron charge

$R_{s^{-}}$Series Resistance, $R_{p} \_$Parallel resistance

$K$ - Boltzman constant

\subsection{Decoupling Capacitor}

Decoupling capacitor (input capacitor) is an energy storage element, used at input side of solar micro inverter 
(ILFI). Decoupling capacitor is used for balance different instantaneous power in the system. Due to the ripple at terminal of PV panel, the utilization ratio is decreased, to avoid this and improve utilization factor, the decoupling capacitor is connected in parallel with PV panel. Also, it gives constant and maximum power to converter by extracting maximum power from PV panel. The value of Decoupling capacitor can be calculated from equation (4). [9]

$$
C_{\text {in }}=\frac{P_{m p p}}{2 \pi \cdot f_{\text {ripple }} \cdot V_{\text {mpp }} \cdot V_{\text {ripple }}}
$$

The value of ripple voltage can be calculated from equation (5).

$$
V_{\text {ripple }}=\sqrt{\frac{\left(K_{p v}-1\right) \cdot 2 \cdot P_{m p p}}{3 . \alpha . . V_{m p p}+\beta}}
$$

Where,

$V_{\text {ripple }}$ - Ripple voltage, $V_{m p p}$ - PV panel Voltage at MPP

$P_{m p p}$ - PV panel Power at MPP, $f_{\text {ripple }}$ - Ripple frequency

$K_{p v}$ - Utilization Factor

$\alpha, \beta$ - Coefficient of second -order Taylor equation

The ripple frequency taken as twice the line frequency, values of $\alpha, \beta, K_{p v}$ is taken from [11]. With the known ripple voltage, required capacitance is calculated. Different PV modules are considered to determine value of $C_{\text {in }}$. Also, the acceptable tolerance for decoupling capacitor is $20 \%$ that must be taken in account [9].

\subsection{Active Clamped Interleaved Fly back Converter}

As shown in Figure 5, an active clamped interleaved fly back converter is connected between decoupling capacitor and unfolding bride. One of the issues about fly back converter topology is to handle leakage energy. When fly back converter switch (MOSFET) is switched off, still there is a large amount of energy in the core of fly back transformer's primary side, which is not transferred to secondary of transformer, so, the voltage across $\mathrm{Sp}_{1}$ (when $\mathrm{Sp}_{1}$ off) is sum of input voltage and feedback voltage. Therefore, large voltage spike are occurs across main switch which is caused due to the resonance between leakage inductance and capacitance of main switch $\mathrm{Sp}_{1}$.

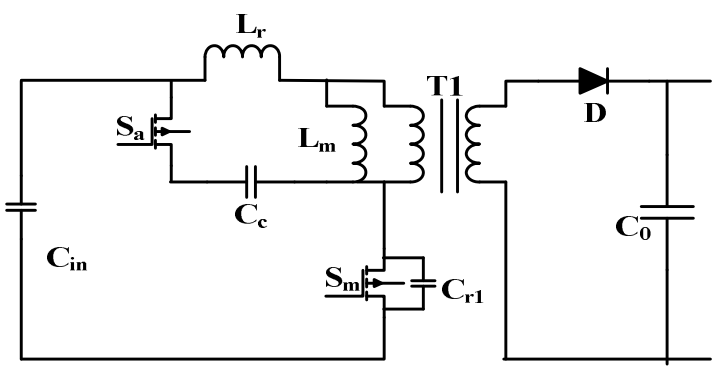

Figure 5: Active Clamp Circuit for Fly back Converter

When voltage spike is increased above the switch rating, then it is very destructive, to switch traditionally, resistor 
capacitor diode RCD snubber are used across primary transformer to dissipate this energy for protecting fly back MOSFET, but it will have negative impact on efficiency of the system. So, lossless snubber i.e. the active clamp circuit is incorporated for the protection of switch from voltage spike and other destruction. This circuit consist of leakage inductance $\mathrm{L}_{\mathrm{r}}$ and clamping capacitor $\mathrm{C}_{\mathrm{c}}$ and auxiliary switch $\mathrm{S}_{\mathrm{a}}$, as shown in Figure 5 .

When using the active clamp circuit in fly back converter, voltage spike is clamped by using clamping capacitor $\left(\mathrm{C}_{\mathrm{c}}\right)$, means leakage energy is stored in clamping capacitor, so, the voltage spike get reduced across the main switch. This stored energy is transferred to the secondary of the transformer and recycle the energy, so, by using the active clamp circuit in fly back micro inverter, it helps to protect converter and also improve the overall efficiency of the system.[7,9,10]

\subsubsection{Design of Resonant Inductor $L_{r}$}

Resonant inductor $\mathrm{L}_{\mathrm{r}}$ represents the total leakage inductance reflected to primary of fly back transformer, also it is called leakage inductance.

$$
\begin{aligned}
& L r \geq \frac{C_{r} \times\left(V_{\text {in }}+N V_{o}\right)^{2}}{I_{\text {smain }}{ }^{2}} \\
& I_{\text {smain }}=\frac{\sqrt{2} \cdot P_{o}}{2 \eta V_{\text {in }} . D}+\frac{V_{\text {in }} \cdot D}{2 L_{m} \cdot f_{\text {sw }}}
\end{aligned}
$$

Value of $L_{r}$ is much less than transformers magnetizing inductance (typically less than 5 to 10 percent) [13].

\subsubsection{Design of Clamp Capacitor $C_{c}$}

Selecting value of clamp capacitor is based on value of resonant inductor

$$
C_{c}=\frac{[1-D \cdot V i n]^{2}}{\pi^{2} L_{r} \cdot f_{s w}^{2}}
$$

Value of $\mathrm{C}_{\mathrm{c}}$ taking so high, is not useful in improvement of clamping performance, hence small value of Cc is sufficient for better clamping performance .[12]

Where,

$C_{c}$ - Clamp capacitor, $L_{r}$ - Resonant inductor

$V_{\text {in }}$ - Input voltage, $V_{o}$ - Output voltage

$\Delta V_{o}$ - Voltage ripple, $N$ - Transformation ratio

$D$ - Duty ratio, $P_{o}$ - Output Power.

$C_{r}$ - Resonant capacitor across main switch

$f_{s w}$ - Switching frequency of switch

$\eta$ - Efficiency of the converter, 
$I_{\text {smain }}$ - Maximum current across main switch

\subsection{Transformer Turns Ratio (N)}

Transformer, which is used in fly back converter circuit, is called as fly back transformer. For calculating turns ratio of fly back transformer, we must know the input voltage of PV, required output voltage and duty cycle. Transformer turns ratio is determine by equation no.10 [9] as follows

$$
N=\frac{\text { Vout }}{\text { Vin.pv }} \times \frac{(1-D)}{D}
$$

Where.

Vout-Required output voltage, D -Maximum Duty cycle

Vin.pv - Input voltage from PV

\subsection{Unfolding Bridge or Single Phase Bridge Inverter}

At the output of the fly back converter, a full bridge type circuit is connected having two legs and each leg has two MOSFET switches. This full bridge is unfolding circuit for rectified output of the interleaved fly back converter, which converts rectified AC of converter to sinusoidal AC, having 220-230 V AC output and 50Hz frequency, which is compatible to the single phase grid. The switching frequency of the switches (MOSFET) is high and switching is given by SPWM technique.[7,9]

\subsection{EMI Filter}

An EMI (Electromagnetic interference) filter is connected at the output of the unfolding bridge because, Filters are used to remove unwanted harmonics from AC output of bridge and reduce THD of the system and harvest harmonic free power to grid. Here, the LC filter is used for filtering the output voltage and current. EMI filter also gives protection from transient voltage spikes.[9]

\section{SIMULATION AND RESULTS}

The modelling \& simulation of interleaved fly back micro inverter is carried out in MATLAB-SIMULINK. Model of ILFI is represented in Figure 6. Switching pulses of main switches $\mathrm{Sp}_{1} \& \mathrm{Sp}_{2}$ of ILFI is shown in Figure 7, which is 180 degree phase shift. The PV input voltage to the converter is $30.5 \mathrm{~V}$ and boost it to $230 \mathrm{~V}$ by using active clamped interleaved fly back converter, as shown in Figure 8. Now, this boost voltage is given to unfolding bridge, which converts this voltage to sinusoidal $230 \mathrm{~V} \mathrm{AC}$, but it contains some harmonics Figure 9 showing output voltage without filter. After connecting LC filter, output voltage becomes sinusoidal $230 \mathrm{~V}, 50 \mathrm{~Hz}$ which is compatible to grid. Figure 10 and Figure 11 shows grid voltage and grid current, respectively. Output power wave form is as shown in Figure 12 give $225 \mathrm{~W}$, which can be harvest to grid. Figure 13 shows THD of output voltage after LC filter is less than $0.33 \%$. Design Parameters of ILFI is as shown in Table 1 


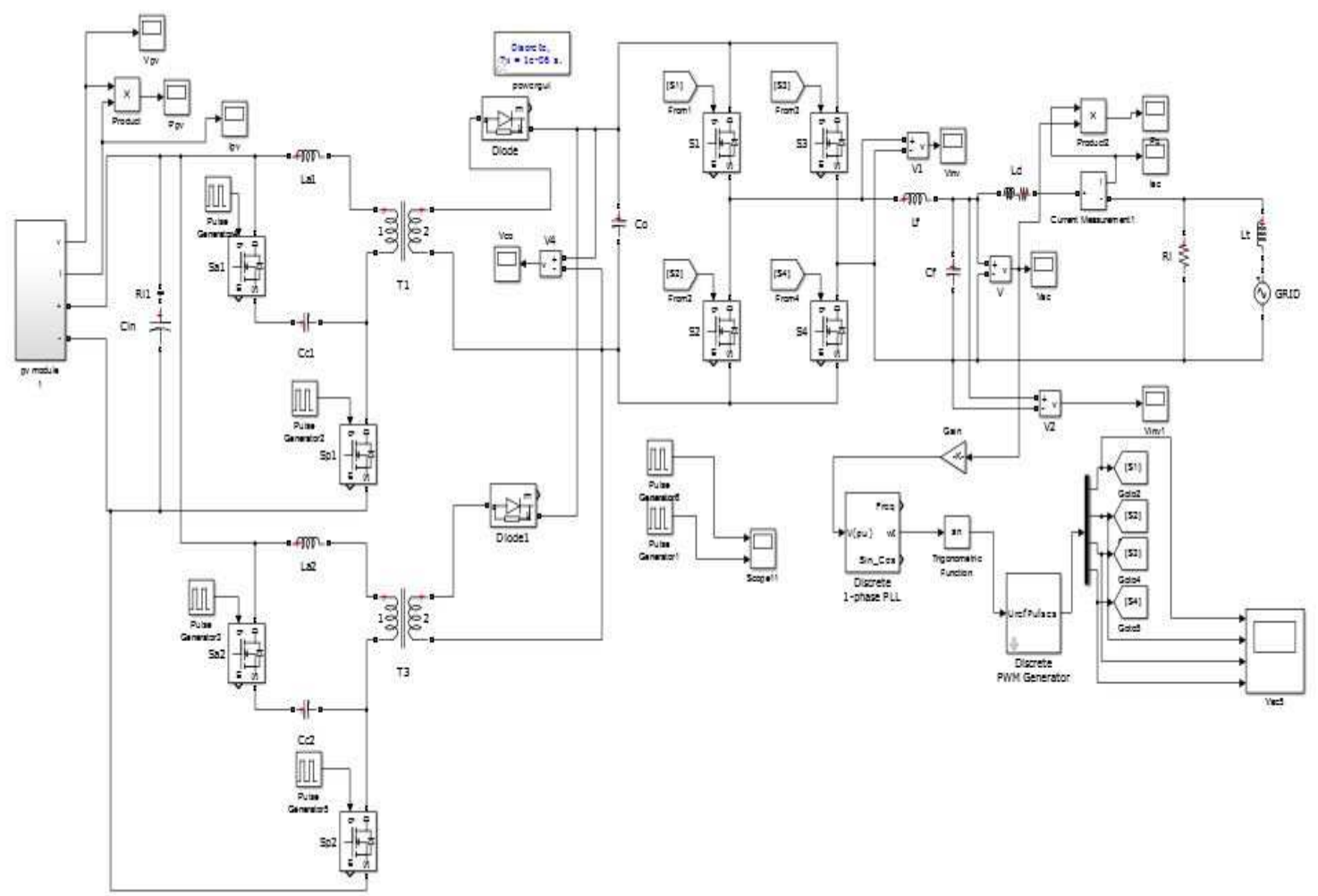

Figure 6: Model of Active Clamped Fly back Based Micro Inverter

Table 1: Design Parameters

\begin{tabular}{|l|c|c|}
\hline \multicolumn{1}{|c|}{ Parameter } & Value & Unit \\
\hline Vin, pv & 30.5 & $\mathrm{~V}$ \\
\hline Pmpp, pv & 250 & $\mathrm{~W}$ \\
\hline Input Capacitance $\mathrm{C}_{\mathrm{in}}$ & 4.10 & $\mathrm{mF}$ \\
\hline Transformation turns ratio & $1: 7$ & - \\
\hline Magnetizing Inductance $\mathrm{L}_{\mathrm{m}}$ & 8.28 & $u \mathrm{H}$ \\
\hline Resonant Inductor $\mathrm{L}_{\mathrm{r}}$ & 0.74 & $u \mathrm{H}$ \\
\hline${\text { Clamping Capacitor } \mathrm{C}_{\mathrm{c}}}$ & 7.28 & $\mathrm{mF}$ \\
\hline
\end{tabular}

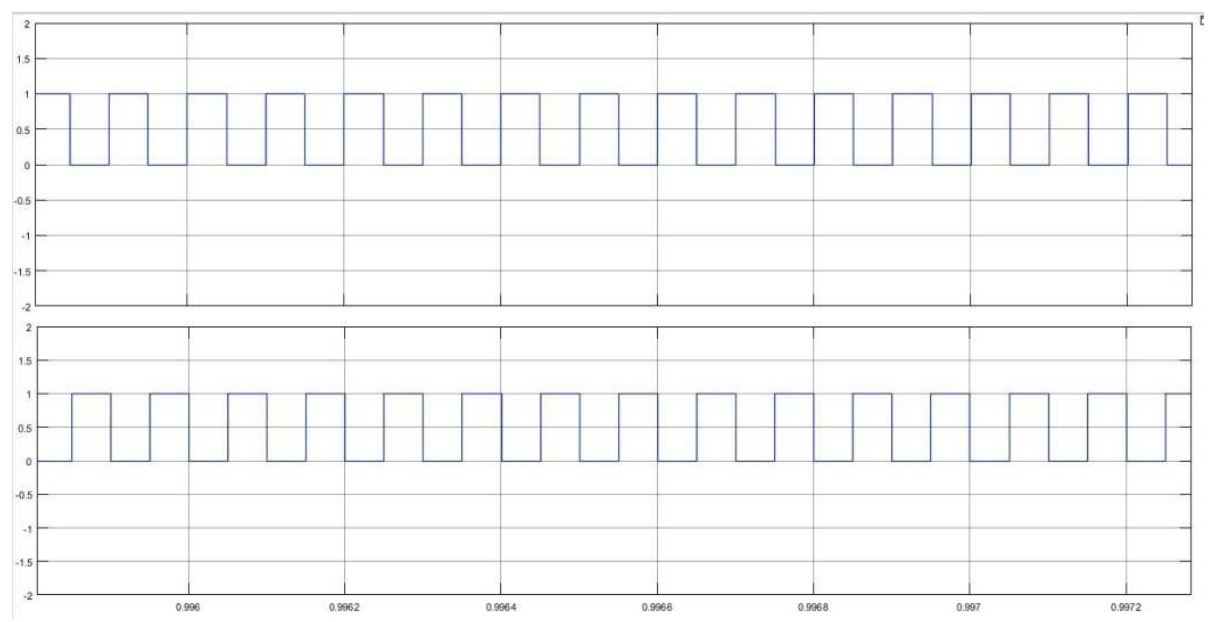

Figure 7: Switching of Sp1 and Sp2 


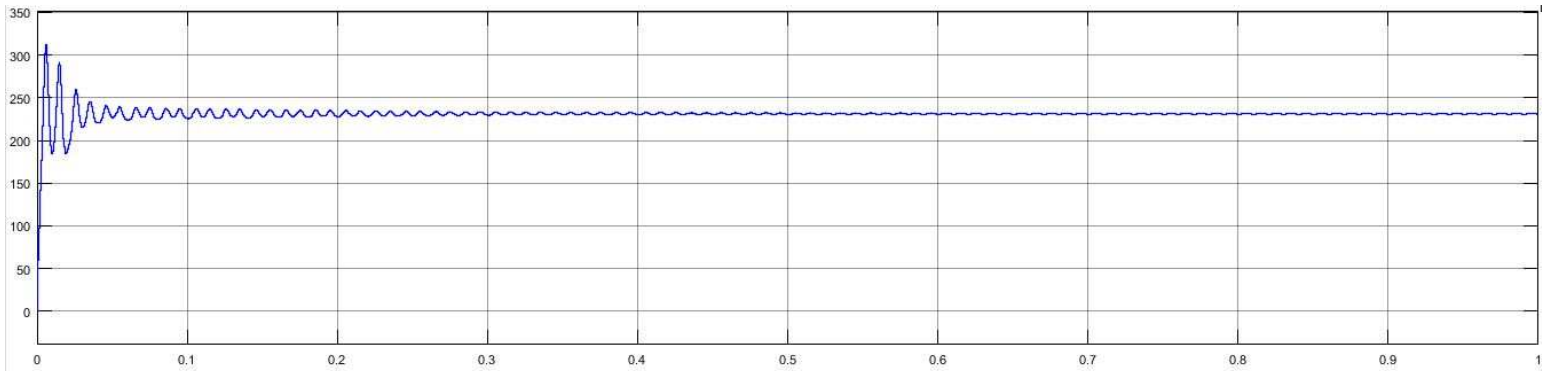

Figure 8: Output Boost Voltage from Converter

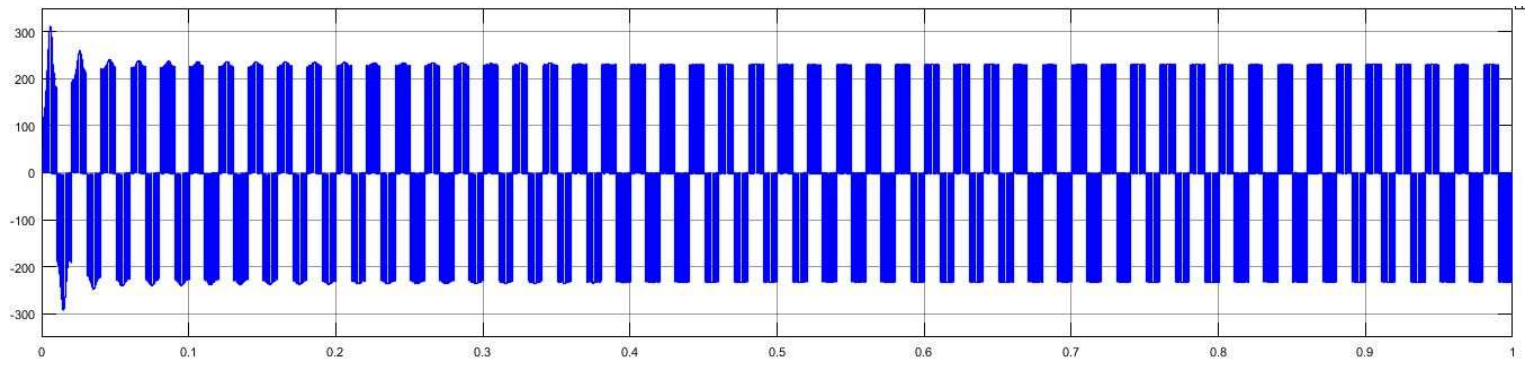

Figure 9: Output Voltage of Inverter without Filter

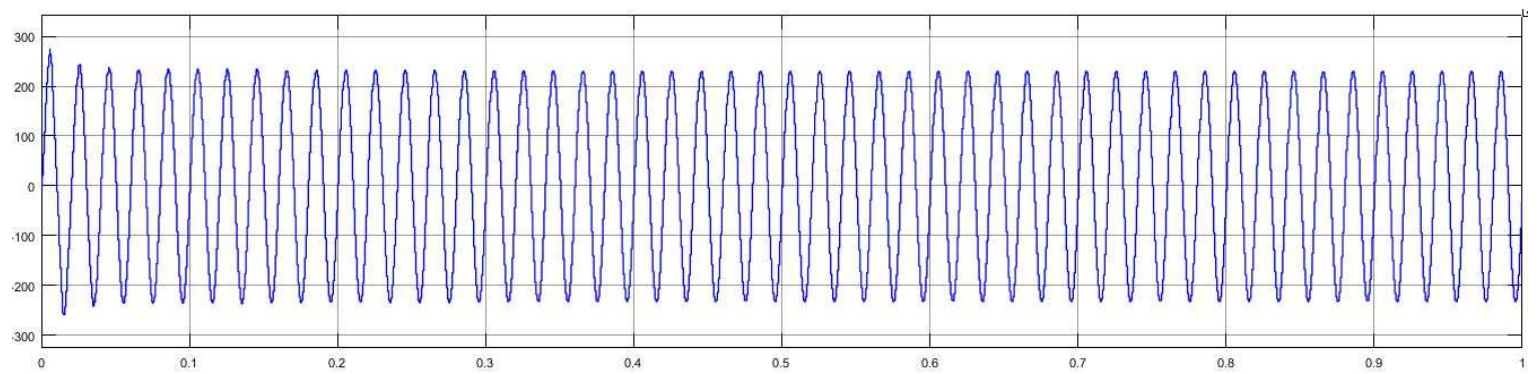

Figure 10: Output Voltage of Inverter after Filter

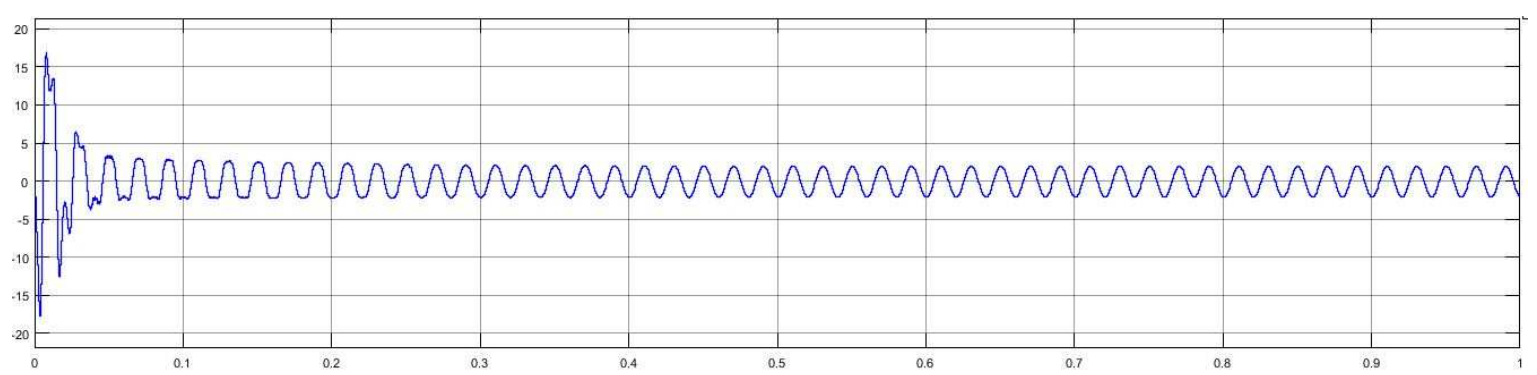

Figure 11: Output Current

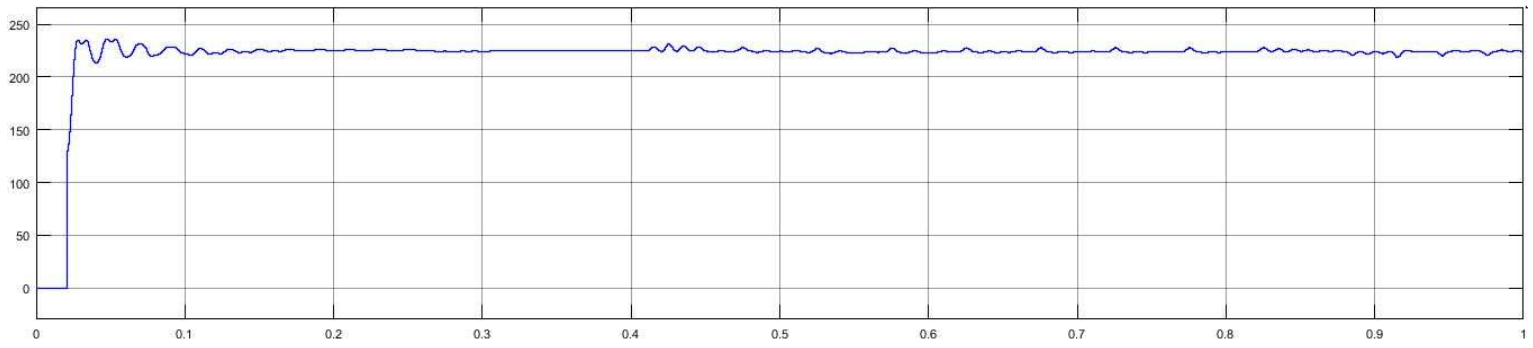

Figure 12: Output Power 


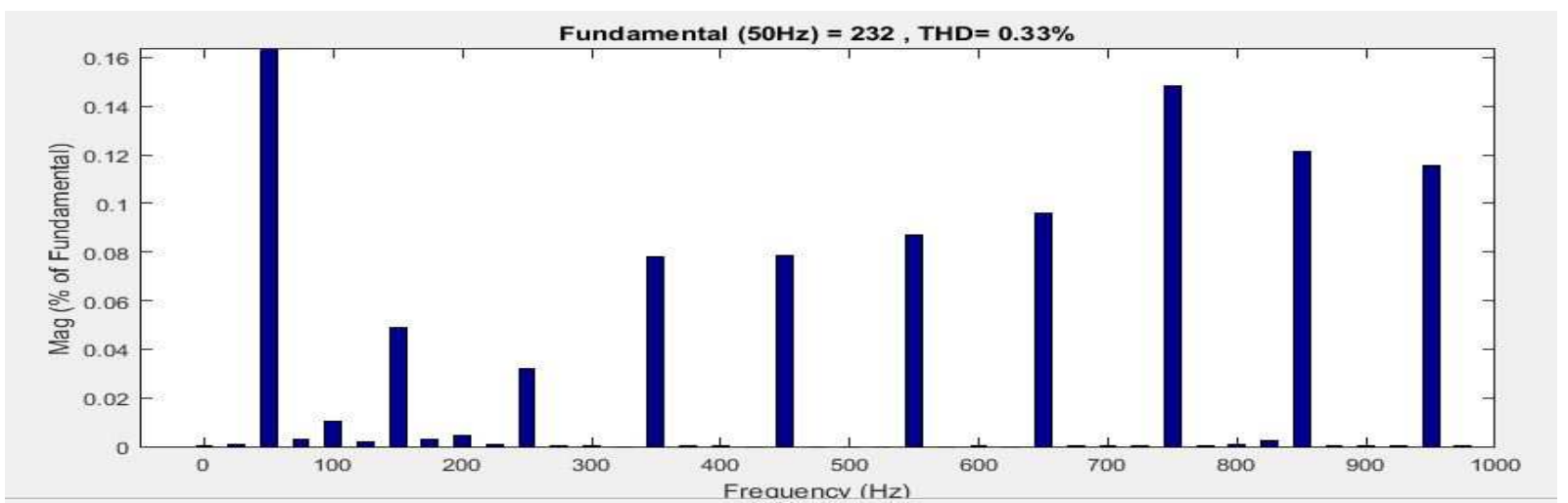

Figure 13: THD of Output Voltage

\section{COMPARISON OF MICROINVERTER WITH STRING INVERTER}

The comparison of micro inverter with string inverter in terms of output power at time of partial shading is performed in MATLAB-Simulink. For comparison, consider micro inverter system having three PV modules of same rating, each panel is connected to its separate low rating micro inverter. In case of string inverter, three PV modules having same rating as in micro inverter system are connected in series, to from string of three PV panels and attached to the high rating string inverter. Both systems are connected to single phase grid and having same load.

Table 2: Power Output of String and Micro inverter

\begin{tabular}{|c|c|c|c|}
\hline Irradiance $\left(\mathbf{W} / \mathbf{m}^{\mathbf{2}}\right)$ & $\begin{array}{c}\text { Power from } \\
\text { String inverter(Watt) }\end{array}$ & $\begin{array}{c}\text { Power from } \\
\text { Micro Inverter(Watt) }\end{array}$ & $\begin{array}{c}\text { \% Increase in Power } \\
\text { by Micro inverter }\end{array}$ \\
\hline 1000 (Full) & 650 & 660 & - \\
\hline 700 & 400 & 460 & $8.3 \%$ \\
\hline 500 & 251 & 415 & $23 \%$ \\
\hline 300 & 99 & 414 & $37 \%$ \\
\hline 100 & 26 & 410 & $55 \%$ \\
\hline
\end{tabular}

To observe the effect of partial shading, change the irradiance of only one module to different level and other two modules are at full irradiance in both the systems. Observe changes in the output power of both the system in Table 2 . According to information in Table 2, power output of micro inverter is more than that of string inverter system, with respect to partial shading (shading on one module). Also, percentage increase in power harvesting, in case of micro inverter is shown in Table 2. The rise in the shading level of one of the modules leads to increase in percentage of power output by micro inverter. So, more power is harvest by micro inverter than string inverter, at partial shading and overall efficiency of system increases.

\section{CONCLUSIONS}

This paper presents the design of active clamped interleaved fly back micro inverter for PV applications and its simulation in MATLAB-Simulink. Outputs based on simulation are good agreement with calculated values and required outputs are obtained. Fly back converter boost the PV voltage to $230 \mathrm{~V}$ DC, and unfolding bridge converts it into grid compatible $230 \mathrm{AC}$ voltage with frequency of $50 \mathrm{~Hz}$ and $\mathrm{THD}<5 \%$. As compared to string inverter, the micro inverter harvest more power to the grid, by reducing shading effect. The micro inverter also gives additional advantages like compact size, reduce mismatch losses, use of DC cables, plug \& play operation, low maintenance and long life span and increase in overall efficiency of PV systems. 


\section{REFERENCES}

1. S. B. Kjaer, J. K. Pedersen and F. Blaabjerg, "A Review of single-phase grid-connected inverters for photovoltaic modules," IEEE Trans. on, Ind. Appl, vol. 41, no 5, pp. 1292-1305,September/October, 2005.

2. http://mnre.gov.in/mission-and-vision2/achievements/

3. Joydip Jana, Hiranmay Saha, Konika Das Bhattacharya, "A Review of inverter topologies for single-phase grid connected photovoltaic systems” Elsevier's Renewable and Sustainable Energy Reviews, pp. 1-15, 2016.

4. Manasseh Obi, Robert Bass, “Trends and challenges of grid connected photovoltaic system”, Renewable and Sustainable Energy Reviews May, pp. 1082-1094, 2016

5. IEEE Std 1547, "IEEE Application guide for IEEE standard for interconnecting distributed recourses with electric power systems" IEEE standard coordinating committee for fuel cell, photovoltaic, dispersed generation pp. 12-60, 15 April 2009.

6. Ching-Ming Lai, "A Single Stage Grid Connected PV Microinverter Based on Interleaved Flyback Converter Topology" International Symposium on Computer, Consumer and Control, pp.187-190, 2014.

7. Young-Ho Kim, Young-Hyok Ji, Jun-Gu Kim, Yong-Chae Jung, and Chung-Yuen Won, "A New Control Strategy For Improving Weighted Efficiency In Photovoltaic AC Module -Type Interleaved Flyback Inverters" IEEE TRANSACTIONS ON POWER ELECTRONICS, VOL.28,NO.6, pp-2688-2699, JUNE 2013

8. Gilbert M. Masters, “Book on Renewable and Efficient Electric Power Systems” John Wiley \& Sons, Inc 2004 pp -460-469

9. Alex Dumais and Sabarish Kalyanaraman," Grid-Connected Solar Microinverter Reference Design” Microchip technology inc. 2012

10. P. Anto Jailyn, Alagu Dheeraj, V. Rajini, "Analysis of Active Clamp Flyback converter" Canadian Center of Science and Education, vol.9,No.1,2015 pp-12-24

11. Søren Bakhфj Kjar, "Design and Control of an Inverter for Photovoltaic Applications" Dissertation submitted to Aalborg University, DENMARK Institute of Energy Technology January 2005

12. Jason Tao, Vieri Xue, “Grid-Connected Micro Solar Inverter Implement Using a C2000 MCU” Texas Instruments Jan-2013 
